\title{
Shipworms as a model for competition and coexistence in specialized habitats
}

\author{
Hugh MacIntosh ${ }^{1, *}$, Rocky de Nys ${ }^{1}$, Steve Whalan ${ }^{1,2}$ \\ ${ }^{1}$ Centre for Sustainable Fisheries and Aquaculture, School of Marine and Tropical Biology, James Cook University,
} Townsville, Queensland 4811, Australia

${ }^{2}$ Marine Ecology Research Centre, School of Environment, Science and Engineering, Southern Cross University, PO Box 157, Lismore, New South Wales 2480, Australia

\begin{abstract}
Shipworms, a group of marine wood borers (Mollusca: Teredinidae), are a model group with which to examine metacommunities inhabiting patchy, ephemeral habitats. Multiple species and genera typically share and compete for the same discrete substrata, allowing for direct comparisons to be made between competitive strategies, without confounding by extraneous biological differences. Timber recruitment panels were used to quantify 2, 4, 6 and 12 mo abundances of tropical Australian shipworm species, recording 62075 individuals from 6 genera and 19 species. Species exhibit differing peak recruitment seasons and reproductive modes, with freespawning, short-term brooding and long-term brooding occurring. However, despite a higher diversity of spawning species (58\%) overall, abundance was strongly driven by the lower diversity of short-term brooding species $(37 \%)$, comprising $95.7 \%$ of recruitment. Competition for habitat was high, with up to 1200 individuals per panel $\left(\sim 3\right.$ ind. $\left.\mathrm{cm}^{-3}\right)$, and widespread (40 to $90 \%$ ) mortality in panels over 4 mo old. Results show that reproductive mode is a key contributor to recruitment success, with the constraints of a patchy, ephemeral habitat favoring a 'middle of the road' strategy of short duration larval brooding, most effectively balancing fecundity, larval retention, and dispersive ability.
\end{abstract}

KEY WORDS: Competition - Coexistence $\cdot$ Metacommunities $\cdot$ Ephemeral habitat $\cdot$ Larval dispersal $\cdot$ Reproductive mode $\cdot$ Teredinidae

\section{INTRODUCTION}

Populations of sessile marine organisms often exist in spatially (Levin \& Whitfield 1994, Hanski 1999) and temporally (Giesel 1976, McPeek \& Holt 1992, Travis \& Dytham 1999) heterogeneous environments. While larval dispersal and recruitment are amongst the most important factors determining adult population maintenance (Levin 2006, Cowen \& Sponaugle 2009, Pineda et al. 2009), post recruitment competition can also be fundamental to population success (Caley et al. 1996, Marshall \& Keough 2009, Burgess \& Marshall 2011). Understanding and quantifying competition amongst coexisting species has been a focus for ecologists using both theoretical (Levins \& Culver 1971, Hanski 2008, Spencer \& Tanner 2008) and empirical approaches (Cadotte et al. 2006, Chadwick \& Morrow 2011, Logue et al. 2011).

In the marine environment, inter- and intraspecific competition often manifests in a variety of reproductive modes and larval dispersal behaviours (Kawecki \& Stearns 1993, Hadfield \& Strathmann 1996, Krug 2001), with larval dispersal occurring over wide (Scheltema 1988) and narrow spatial scales (Swearer et al. 1999). However, despite the advances in our understanding of larval dispersal, recruitment and competition, much of the empirical work to date has focused on individual invertebrate species, in part due to the complexity associated with recruitment dynamics (Pineda et al. 2009). While this single-species approach has been useful in providing information on processes such as larval dispersal (Shanks 1995) and 
planktonic mortality (Vaughn \& Allen 2010), identifying the relative effectiveness of competitive strategies requires either detailed retesting of successive target species, or examining competition between unrelated species. This 'apples and oranges approach' risks making inferences about the competitive strategies of species, when advantage may be due in part to differing underlying anatomies, physiologies or locations. An ideal approach would be to target a taxon with multiple species or genera that share and compete for the same discrete substrata - allowing for direct comparisons to be made as to the effectiveness of competitive strategies, without confounding by any extraneous biological differences.

Shipworms (Family Teredinidae) are highly derived lamellibranch bivalves that are obligate woodfeeders, and as such are limited to a substratum that is both sparsely distributed and often uncommon in the marine environment (Alix 2005, Hinojosa et al. 2011). The reduced shells and wormlike bodies of the sessile adults facilitate growth, via burrowing, into woody plant tissue. This mechanical action of burrowing by many coexisting individuals and species steadily destroys the host timber, resulting in shortlived and highly competitive populations. The life history and dispersive strategies of shipworms have evolved accordingly to exploit these ephemeral habitats, and shipworms can be broadly grouped by reproductive mode. Broadcast-spawning species release gametes or fertilized eggs into the water column for a full, planktotrophic development of 20 to 25 d (Nair \& Saraswathy 1971, Culliney 1975). In contrast, short-term brooders hold fertilized eggs in specialized gill pouches for 5 to $8 \mathrm{~d}$, and release swimming, planktotrophic larvae that reach competency in 10 to $15 \mathrm{~d}$ (Calloway \& Turner 1988), while longterm brooders release large, non-feeding, highly competent larvae capable of settling in hours to days (Calloway \& Turner 1988). Consistent with the literature for other benthic invertebrates (Blueweiss et al. 1978, Strathmann \& Strathmann 1982), brooding is correlated with a smaller body size (Cragg et al. 2009) and lower clutch size, compared to free-spawning species (Calloway \& Turner 1988), which grow larger (Haderlie \& Mellor 1973) and have prodigious fecundities estimated at $10^{6}$ or higher per adult (Scheltema 1971).

Much of the research conducted on shipworms has focused on the economic impacts of their recruitment and growth, and the resistance of various wood species to borer damage (Haderlie 1983, Cookson 1990, Cookson \& Woods 1995). However, recent work has begun to examine shipworms from a broader eco- logical perspective, and identifies that the level of coexistence within the patchy, specialized habitat of shipworms makes them a useful taxon for examining recruitment dynamics and competitive strategies of benthic invertebrates (Cragg et al. 2009). The woodfeeding niche of shipworms means that growth and feeding are synonymous, and the competition faced by shipworm species is directly correlated with their abundance and diversity within wood habitat. Furthermore, shipworms have few known predators (Nair \& Saraswathy 1971) or other competitors within wood, so shipworm communities are shaped primarily by interactions between and amongst shipworm species, and by environmental effects.

Tropical Australian waters support a high diversity and abundance of shipworms (Cookson \& Scown 1999), making it an ideal location to investigate the biology of co-occurring and competing species, and the mechanisms that enable regional coexistence in the absence of habitat partitioning. The numerous species in the region form a competitive metacommunity, and the scattered habitats available can be viewed as a patch dynamic paradigm in modern metacommunity theory (Leibold et al. 2004). As such, the goals of this research were to quantify patterns of seasonality, recruitment and diversity in tropical Australian shipworm species, to examine modes of inter- and intra-specific competition amongst cooccurring shipworm species, and to explore shipworms as a metacommunity model in understanding patterns of coexistence and the relative contributions of competitive strategies.

\section{MATERIALS AND METHODS}

Wooden panels were used to quantify larval recruitment abundance, seasonality and adult demographics. Panels comprised 6 separate $2 \mathrm{~mm}$ thick layers of radiata pine Pinus radiata bolted together between 2 Perspex sheets, following Manyak (1982) and Junqueira et al. (1991). The final dimensions of panels were $220 \times 150 \times 12 \mathrm{~mm}$ (Fig. 1), with a total area of $816 \mathrm{~cm}^{2}$ available for recruitment. The use of these panels allowed larvae to settle and for unimpeded growth by adults. The separate layers of wood in the panels allow easy deconstruction, facilitating the removal of intact individuals.

Panels were deployed at 3 sites in northern Queensland, Australia: the Australian Institute of Marine Science (AIMS), Cape Cleveland (19¹6'37.02" S, $\left.147^{\circ} 03^{\prime} 31.46^{\prime \prime} \mathrm{E}\right) ;$ White Lady Bay, Magnetic Island $\left(19^{\circ} 06^{\prime} 29.85^{\prime \prime} \mathrm{S}, 146^{\circ} 51^{\prime} 42.73^{\prime \prime} \mathrm{E}\right)$; and Pioneer Bay, 

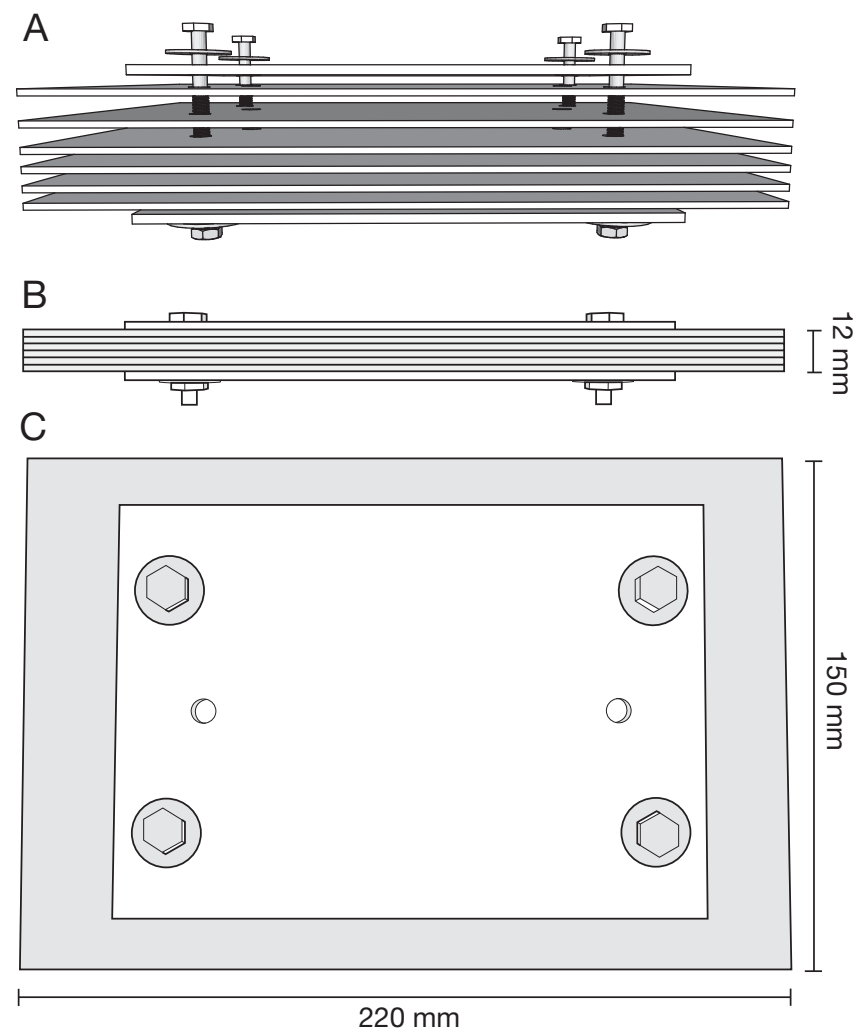

Fig. 1. Design of recruitment panel. (A) Expanded schematic, showing 6 layers of $2 \mathrm{~mm}$ thick radiata pine held together by steel bolts between 2 sheets of plexiglas. (B) Side view. (C) Face view. Attachment to rope lines facilitated by 2 remaining holes

Orpheus Island $\left(18^{\circ} 36^{\prime} 14.70^{\prime \prime} \mathrm{S}, 146^{\circ} 29^{\prime} 14.48^{\prime \prime} \mathrm{E}\right)$ (Fig. 2). To record seasonal variation in recruitment, panels were submerged for 1, 2, 4, 6 and $12 \mathrm{mo}$, with 6 replicate panels per month, then collected and replaced (destructive time series sampling), starting in the Austral winter, July 2007. Because of logistical constraints, 1 mo collections were not used at Magnetic and Orpheus Islands. At each site, panels were distributed randomly in pairs along floating long lines, hanging at depths of $1.5 \mathrm{~m}$ for a total of 12 pairs of hanging panels. Water depth ranged from 3 to $10 \mathrm{~m}$ with a soft sediment benthos. The surrounding coastal habitat was dry tropical forest with fringing mangroves.

Panels collected from each time point were gently cleaned to remove light external fouling, fixed with $5 \%$ formalin in seawater for $2 \mathrm{wk}$ and subsequently stored in $70 \%$ ethanol pending analysis. To quantify recruitment, each panel was then carefully opened and all shipworms were removed. As shipworm identification relies almost exclusively on the morphology of calcareous 'pallet' structures at the animal's poste-

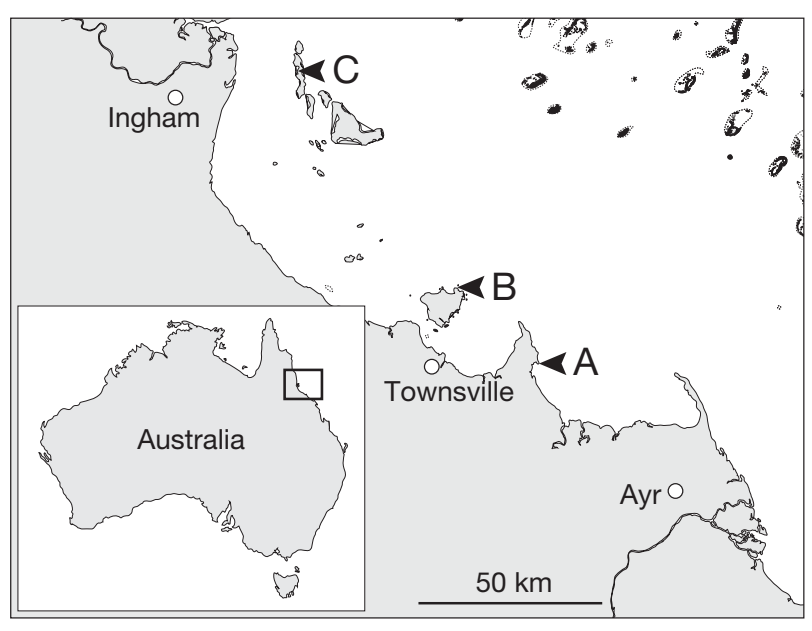

Fig. 2. Study sites in North Queensland, Australia. (A) Australian Institute of Marine Science (AIMS), Cape Cleveland. (B) White Lady Bay, Magnetic Island. (C) Pioneer Bay, Orpheus Island

rior (Turner 1966), care was taken to ensure specimens were removed intact. Each shipworm only makes one burrow, and this remains after death, therefore a burrow count provides a value of total recruitment to a panel. Intact individuals provide a value of living adults occupying the panel at time of collection. The difference between these 2 values represents the total mortality experienced by settled adults. All specimens retrieved were identified to species level, photographed and measured (length and width) using ImageJ analysis software. Species identifications and their modes of reproduction were verified against collections in the Australian Museum, Sydney.

Recruitment data were plotted according to the age of the panel, site and time, in order to visualize temporal and spatial recruitment patterns. Further analysis with PRIMER v6 (Clarke \& Gorely 2006) consisted of principal component analyses (PCA) to determine species weighting across the sample period, and multivariate analysis of similarities (ANOSIM) to generate pair-wise statistical comparisons between sites and age treatments. To avoid undue weighting by species at extremes of abundance, scarce species were omitted from analysis (see 'Results'), with the remaining data log transformed.

\section{RESULTS}

\section{Species diversity}

From 6 genera of Teredinidae, 19 species were recorded across all panels (Table 1), with a total of 
Table 1. Presence/abundance matrix of shipworm species at study sites (Australian Institute of Marine Science [AIMS], Orpheus and Magnetic Islands), ranked in decreasing abundance for both brooding (unshaded) and spawning (shaded) species. Total abundance per site is listed beneath

\begin{tabular}{|c|c|c|c|}
\hline Species & AIMS & Magnetic Island & Orpheus Island \\
\hline Lyrodus tristi & & & $\cdot$ \\
\hline Teredo parksi & & & - \\
\hline Lyrodus floridanus & & & - \\
\hline Lyrodus turnerae & O & & - \\
\hline Teredo johnsoni & - & $\cdot$ & \\
\hline Lyrodus bipartita & - & & \\
\hline Lyrodus massa & • & & \\
\hline Lyrodus pedicellatus & • & & \\
\hline Bankia carinata & - & - & - \\
\hline Bankia gracilis & $\bullet$ & • & \\
\hline Bankia neztalia & - & - & - \\
\hline Psiloteredo healdi & - & - & \\
\hline Dicyathifer manni & - & & \\
\hline Teredothyra excavata & & • & \\
\hline Bankia bipalmulata & & • & \\
\hline Bankia australis & & • & \\
\hline Bankia tanzensis & & & • \\
\hline Bankia brevis & • & & \\
\hline Teredothyra matocotana & & - & \\
\hline \multirow{2}{*}{$\begin{array}{l}\text { Total: } \\
>7500\end{array}$} & 45415 & 15812 & 848 \\
\hline & -7500 & $\begin{array}{l}5000 \\
2500\end{array}$ & $\begin{array}{ll} & 500-1000 \\
- & 100-500 \\
\bullet & 10-100 \\
\cdot & 1-10\end{array}$ \\
\hline
\end{tabular}

62075 individuals. Spawning and short-term brooding species were both present, with spawning species comprising $58 \%$ of species and short-term brooders comprising $37 \%$. Only 1 long-term brooding species (Lyrodus pedicellatus) was recorded. Of the 19 species, 11 were recorded intermittently across the year or in too low an abundance to make accurate inferences about their seasonality or demo- graphics, other than their relative scarcity. Further analyses examined data for the 4 most abundant brooding (L. tristi, Teredo parksi, L. floridanus and L. turnerae) and spawning (Bankia carinata, B. gracilis, B. neztalia and Psiloteredo healdi) species, totaling $99.7 \%$ of all recruitment, with each recorded in at least 2 sites for at least 2 sample periods.

\section{Recruitment and abundance}

Panels were settled by shipworms year-round, with peak intensities in March and May (Fig. 3A). At AIMS, 1 mo panels, sampled at a finer resolution, showed similar levels of recruitment to 2 mo panels, indicating that the majority of recruitment in a given panel occurred between 1 and 2 mo of age. At AIMS, mean 2 mo panel recruitment ranged from 130 $( \pm 42)$ individual (ind.) shipworms per panel in the winter and spring months of September and November, to $>1200$ $( \pm 132)$ ind. per panel in the autumn peak of May, before falling sharply again in July (Fig. 3A). At AIMS, 4 mo old panels displayed similar trends but with a later peak, as less frequent sampling expressed May recruitment as part of the final July collection. Adding the total recruitment across all panel ages showed decreased recruitment with panel age, particularly in 4 to 6 mo old panels (Fig. 3B). This was most clearly observed in 12 mo panels, where despite exposure for a year, recruitment was at levels more consistent with the first 4 mo of measurement.

Magnetic Island and Orpheus Island received significantly lower recruitment rates (ANOSIM, r > 0.7, p = 0.001), but patterns of seasonality and abundance mirrored that of AIMS. At all sites high mortality rates, indicated by empty burrows, were measured in treatments 4 mo and older, ranging from 40 to $90 \%$ (Fig. 3A). High mortality in a panel reduced the accuracy of ascertaining species composition. Low mortality ( 0 to $30 \%$ ) in 2 mo treatments again provided a much more accurate representation of seasonal re- 


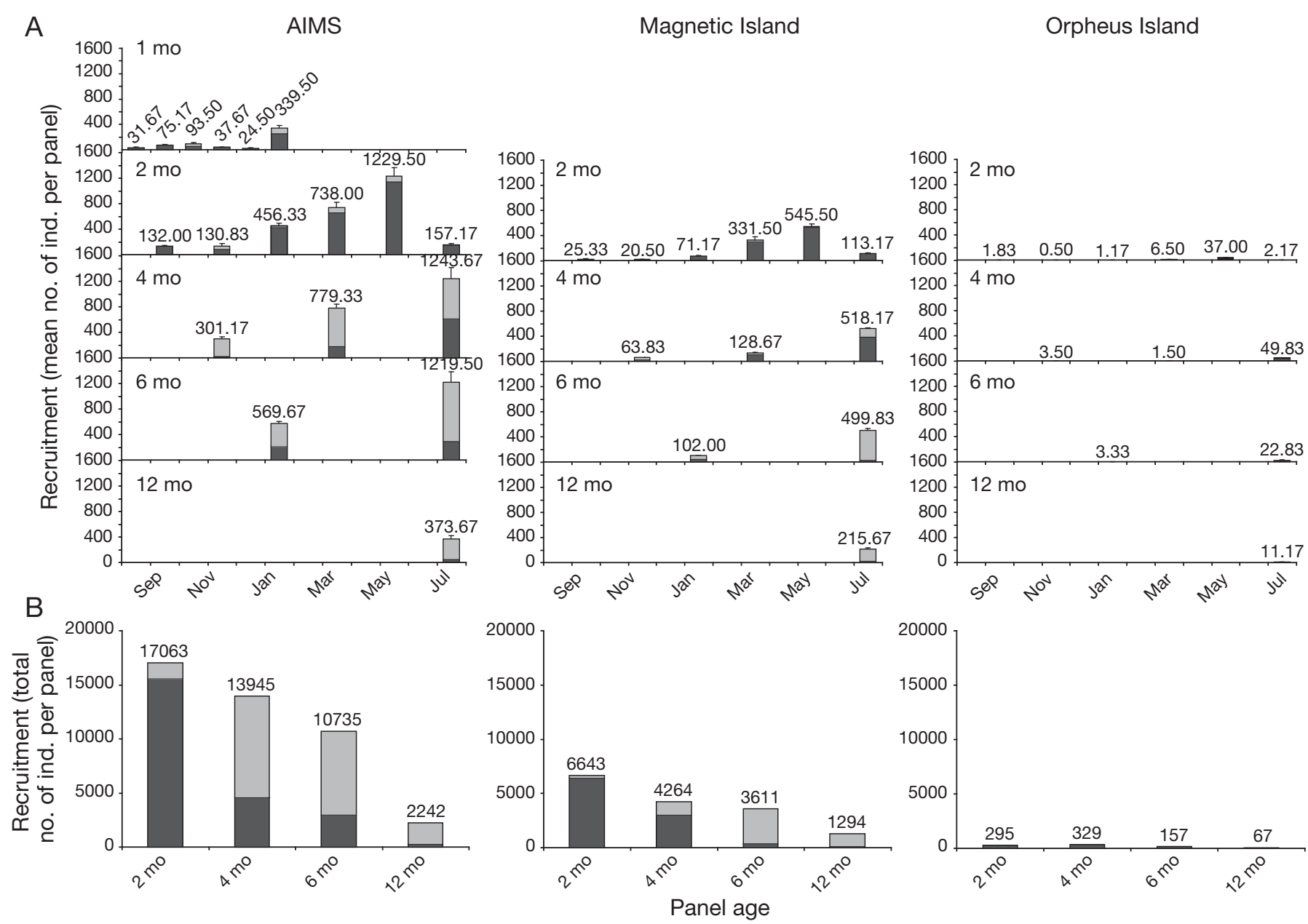

Fig. 3 (A) Monthly recruitment of shipworms (means \pm SE) by age of panel and (B) cumulative recruitment of shipworms to panel age treatments at AIMS, Magnetic Island and Orpheus Island. Recruitment values: above each bar. Light gray portion of bar: dead individuals. See study sites in Fig. 2

cruitment. Increasing mortality with age occurred at all sites regardless of overall recruitment, suggesting that mortality was driven by the age of the habitat, and is not dependant on density-related competition.

PCA demonstrated that different species of shipworms drive recruitment abundance at different times across the year, with a high $(>75 \%)$ percentage of variation accounted for by the first 2 components in all age treatments and sites (Fig. 4). In 2 and 4 mo treatments, clear separation between months was visible within the ordination, with strong associations by groups of species driving patterns of abundance. In 6 and 12 mo treatments, high mortality resulted in less distinct groupings of month groups.

At AIMS, 2 and 4 mo treatments were driven by 2 groups of species. This is clearly seen in the ordination where the first group, made up of Lyrodus floridanus and Bankia gracilis, drove the majority of recruitment in January while the second group, made up of Teredo parksi, L. tristi, L. turnerae and B. carinata, composed the majority of recruitment abundance in May (Fig. 4A,B). January and May represent 2 peaks in recruitment for these species at AIMS. At Magnetic Island 2 and 4 mo panels, L. tristi, $L$. turnerae and $L$. floridanus were contributors to a peak in January and March, while T. parksi, B. carinata and $B$. neztalia were associated with a May peak (Fig. 4E,F). At Orpheus Island, accurate inferences could not be made, as recruitment by all species was low, resulting in fewer distinct vectors on the ordination (Fig. 4I-L).

While a PCA quantifies the contributions of different species over time, it is difficult to visualize recruitment patterns on a per-species basis. For direct comparison, the abundance of each species across all sites and times was graphed (Fig. 5). At all 3 sites, the most abundant species recruit year-round, and peak recruitment occurred between January and May. 

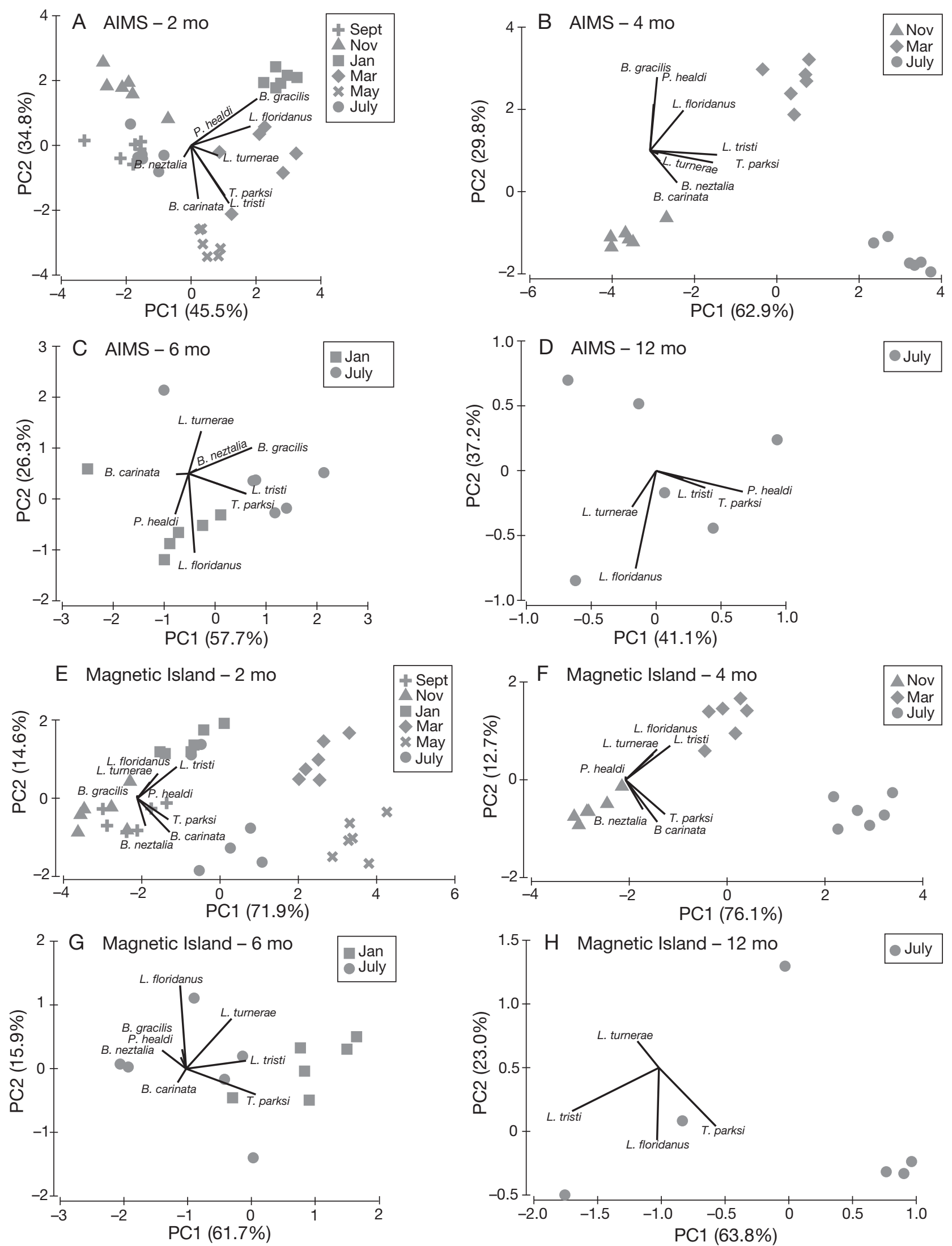

Fig. 4. Principal component analysis (PCA) of shipworms (Lyrodus, Teredo, Bankia and Psiloteredo spp.) contributing to recruitment across sites and panel ages. Sampling months are indicated. Principal components (PCs) with percentage of variation explained (in parentheses). (A-D) AIMS, (E-H) Magnetic Island, (I-L) Orpheus Island. See study sites in Fig. 2 

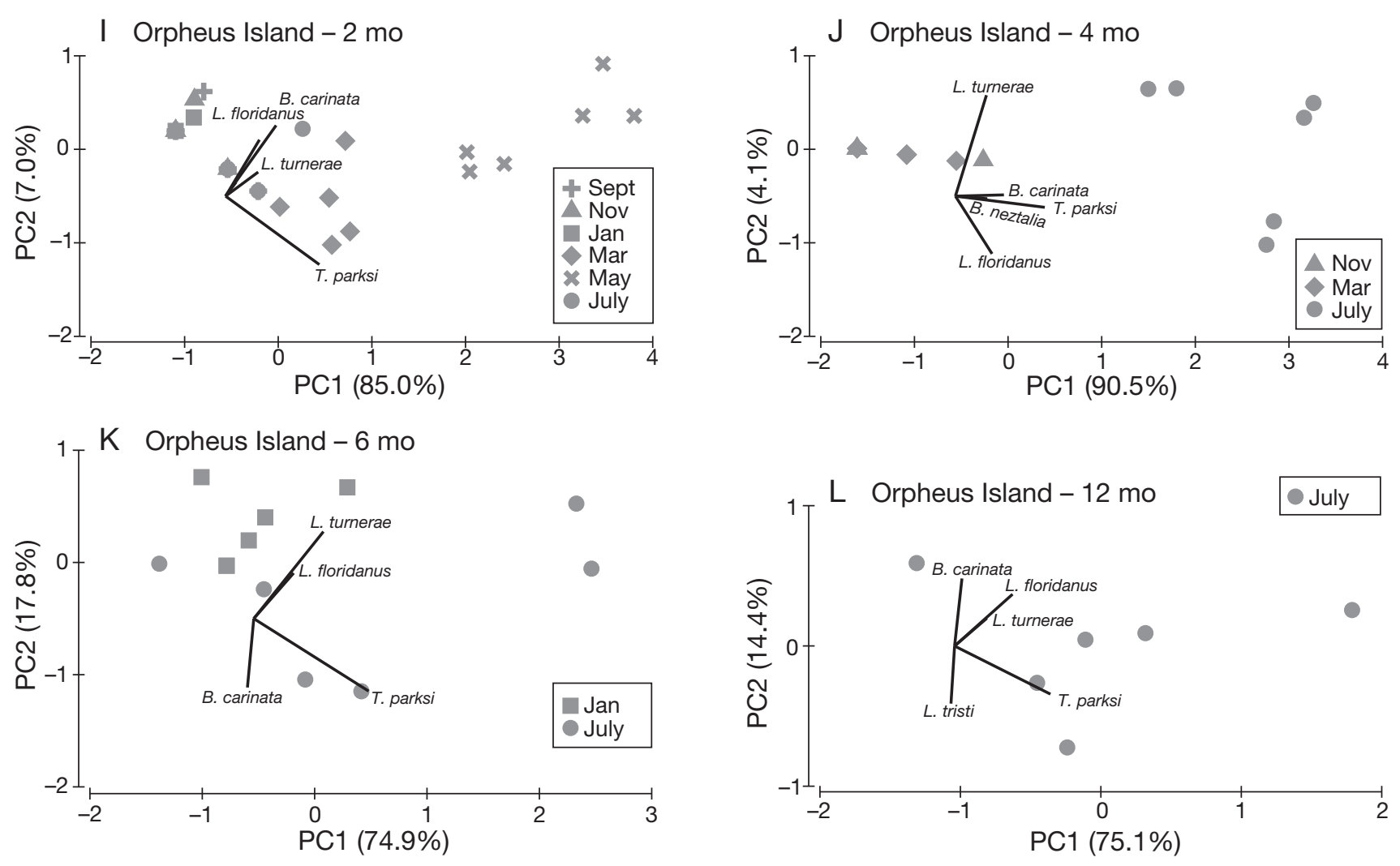

Fig. 4 (continued)

Matching the PCA results, each species exhibited a peak in recruitment. For example, Lyrodus floridanus and Bankia gracilis peaked in January and March, L. tristi, Teredo parksi, L. turnerae and B. carinata peaked in March and May, and B. neztalia peaked in July. Despite a higher number of spawning species, recruitment by short-term brooding species was notably higher than that of free-spawning species, with brooders comprising $95.7 \%$ of recorded abundance. Only one individual of a long-term brooding species (L. pedicellatus) was found, with all other brooders being short-term.

Two-way nested ANOSIM (Month[Age]) of each site showed significant differences in species composition and abundance between panel ages and over time $(\mathrm{R}>0.3, \mathrm{p}=0.001)$. One-way ANOSIMgenerated pairwise tests of 2 mo panels showed significant differences between all months at AIMS (Table 2A) and all but September and November at Magnetic Island (Table 2B), demonstrating that the abundance and composition of species assemblages exhibit significant variation. At Orpheus Island there was no significant difference in recruitment for months outside of the March and May peak season (Table 2C).

\section{DISCUSSION}

The broad findings of this study highlight the dynamic life history of shipworms, an ecologically and economically important invertebrate group that utilizes a sparsely distributed, highly-specific habitat in the marine environment. Shipworm populations exist as highly competitive metacommunities in patchy, ephemeral habitats, and employ different reproductive modes and seasonality to overcome these limitations and seek competitive advantage. Shipworm diversity can be categorized into broadcast-spawning and brooding species, and the relative effectiveness of these strategies can be assessed. Despite the higher diversity of broadcast spawning species, abundance at all sites, ages and months was strongly driven by short-term brooding species, indicating that the constraints of shipworms' niche favor a life history strategy balancing fecundity, larval retention and dispersive ability. The different reproductive strategies employed by tropical Australian shipworms represent different levels of investment in colonization ability and dispersal, enabling regional coexistence of species despite a lack of habitat partitioning. This fits the predictions of patch-dynamic 


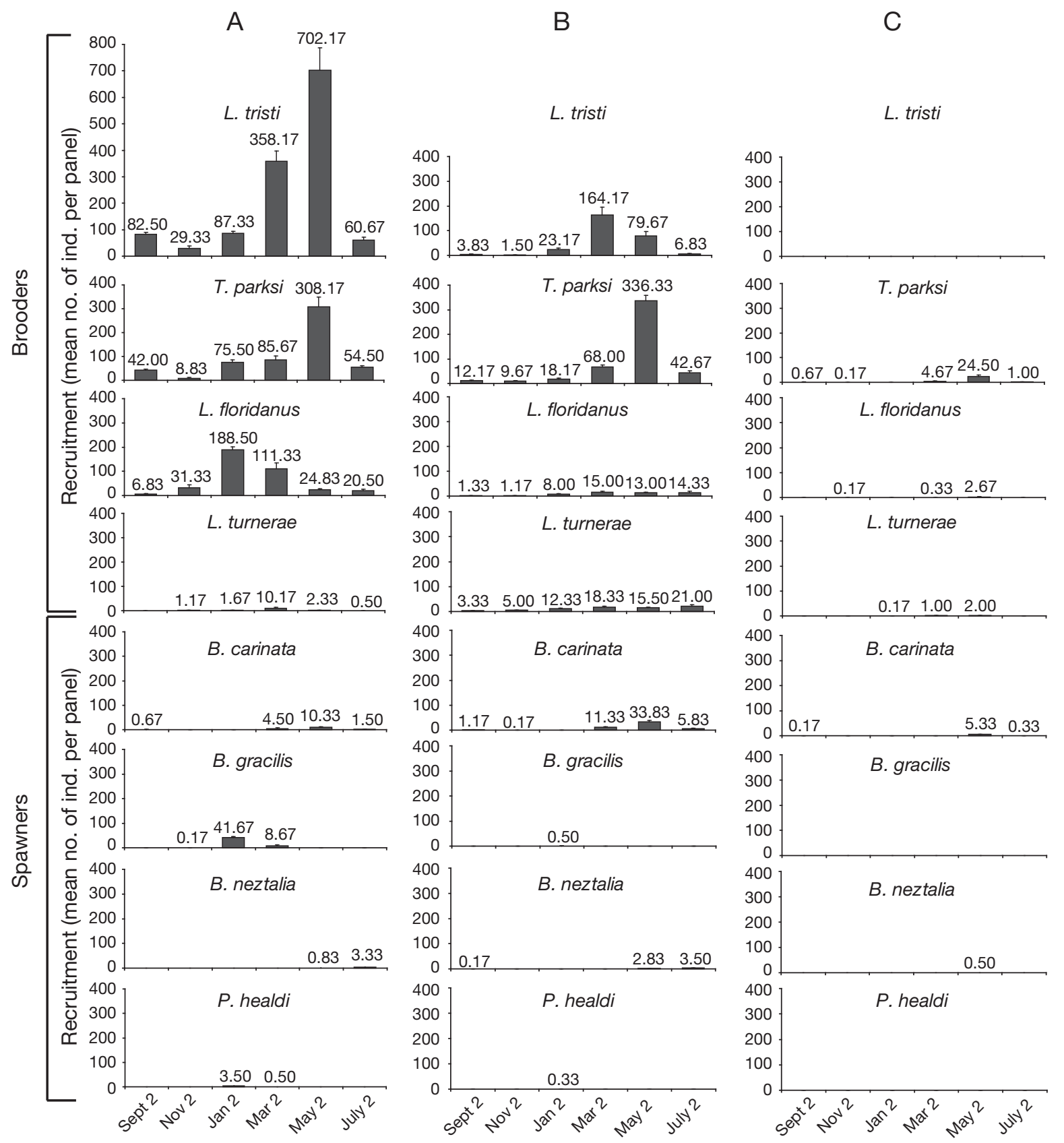

Fig. 5. Abundance (means $\pm \mathrm{SE}$ ) of shipworms of Lyrodus, Teredo, Bankia and Psiloteredo spp. in 2 mo recruitment panels at (A) AIMS, (B) Magnetic and (C) Orpheus Islands. Separation into brooding and spawning reproductive modes is noted. See study sites in Fig. 2

paradigms (Levins \& Culver 1971) and supports shipworms as a useful model group for examining competition within metacommunities.

The year-round larval recruitment that occurs is consistent with past reports on the reproduction of tropical Australian shipworms (Smith 1963, Ibrahim 1981), with 2 mo panels providing discrete measurements of recruitment across a 12 mo period. This perennial reproduction, early maturation and high fecundity (Turner 1966, Nair \& Saraswathy 1971) produces constant larval supply, but given the specificity of shipworm habitat, also highlights the competitive stress for these communities. This stress can be spatial, whereby most of a panel is occupied (e.g. $>1200$ ind. recruiting to a single panel, resulting in a density of $\sim 3$ ind $\mathrm{cm}^{-3}$ ), as well as temporal, with high mortality rates observed in panels over 4 mo of age. While these stresses are likely to be dependent 
Table 2. ANOSIM 1-way pairwise tests of species composition between 2 mo recruitment panels at (A) Australian Institute of Marine Science (AIMS), (B) Magnetic and (C) Orpheus Islands. ANOSIM R-statistic with p-value in parentheses. Significant results in bold

\begin{tabular}{|c|c|c|c|c|c|c|}
\hline & September & November & January & March & May & July \\
\hline \multicolumn{7}{|l|}{ A) AIMS } \\
\hline September & - & - & - & - & - & - \\
\hline November & $0.742(0.002)$ & - & - & - & - & - \\
\hline January & $1(0.002)$ & $0.959(0.002)$ & - & - & - & - \\
\hline March & $0.991(0.002)$ & $0.961(0.002)$ & $0.806(0.002)$ & - & - & - \\
\hline May & $0.991(0.002)$ & $0.978(0.002)$ & $1(0.002)$ & $0.937(0.002)$ & - & - \\
\hline July & $0.617(0.002)$ & $0.820(0.002)$ & $1(0.002)$ & $0.988(0.002)$ & $0.974(0.002)$ & - \\
\hline \multicolumn{7}{|c|}{ B) Magnetic Island } \\
\hline September & - & - & - & - & - & - \\
\hline November & $0.087(0.221)$ & - & - & - & - & - \\
\hline January & $0.897(0.002)$ & $0.897(0.002)$ & - & - & - & - \\
\hline March & $1(0.002)$ & $1(0.002)$ & $0.922(0.002)$ & - & - & - \\
\hline May & $1(0.002)$ & $1(0.002)$ & $1(0.002)$ & $0.767(0.002)$ & - & - \\
\hline July & $0.981(0.002)$ & $1(0.002)$ & $0.693(0.006)$ & $0.650(0.002)$ & $0.707(0.002)$ & - \\
\hline \multicolumn{7}{|c|}{ C) Orpheus Island } \\
\hline September & - & - & - & - & - & - \\
\hline November & $0.019(0.416)$ & - & - & - & - & - \\
\hline January & $0.158(0.106)$ & $0(1.0)$ & - & - & - & - \\
\hline March & $0.293(0.006)$ & $0.512(0.004)$ & $0.736(0.002)$ & - & - & - \\
\hline May & $0.368(0.002)$ & $0.510(0.002)$ & $0.708(0.002)$ & $0.924(0.002)$ & - & - \\
\hline July & $-0.100(1.0)$ & $0.106(0.242)$ & $0.316(0.061)$ & $0.324(0.004)$ & $0.529(0.002)$ & \\
\hline
\end{tabular}

on the size of the wood habitat, the ability of shipworm larvae to assess habitat age or size as a function of its quality remains unknown. Our findings show that in addition to using year-round spawning to increase larval supply, faced with high interspecific competition, shipworm species have different peak reproductive seasons, which increases the relative proportion of their larvae returning to wood substrata at different times of the year. In sampling 2 mo panels, Lyrodus floridanus, Bankia gracilis and Psiloteredo healdi reached peak recruitment in January-March, L. tristi and L. turnerae in March-May, Teredo parksi and B. carinata in May, and B. neztalia in July. Staggered peak reproductive seasons suggest that even comparatively rare shipworm species such as B. gracilis or B. neztalia provide a higher proportion of their larvae recruiting to new habitat independently of one another, reducing interspecific competition.

Dead woody plant tissue, as the obligate habitat for shipworms, is extremely patchy in the marine environment, with high variation in the abundance, size and life span of wood debris (Alix 2005, Hinojosa et al. 2011). Due to the limited life span of wood substrata, it is unlikely that philopatric recruitmentlarvae returning and recruiting to the same source habitat from which they were released-is advantageous. Indeed, as shipworms gradually destroy their habitat by boring and growing into wood, producing larvae with extended planktonic larval phases is a more plausible scenario, as is often the case for other marine invertebrate larvae (Levin 2006, Cowen $\&$ Sponaugle 2009). Nevertheless, the roles endogenous recruitment, or larger scale dispersal, play in shipworm population maintenance is to our knowledge unknown. Low habitat permanence and high habitat patchiness are known to strongly influence the recruitment dynamics of organisms (Travis \& Dytham 1999), with the benefits of new habitat outweighing the risks associated with planktonic larval dispersal.

Faced with competition for limited habitat resources, and with the need to balance self-recruitment and dispersal, the different reproductive modes of shipworm species reflect ways in which species can become more competitive with regard to fecundity and the size or dispersive ability of larvae. Both numbers of larvae and their dispersal capability may play critical roles in their recruitment success, given the relatively scarce nature of wood in the marine environment. The effectiveness of these strategies can be readily examined, and our 
results show that despite more species of freespawners occurring overall, at all sites abundance was clearly driven by short-term brooders in the genera Lyrodus and Teredo. Broadcast-spawning of gametes hedges on high fecundity and a longer larval period, with dispersal recorded even at oceanic scales (Scheltema 1971), but is often constrained by variable rates of fertilization (Levitan 1995, Yund 2000), high mortality of early embryos (Vaughn \& Allen 2010) and poor early swimming ability (Culliney 1975, Koehl \& Hadfield 2010). Long-term brooding, by releasing competent, non-feeding larvae, allows for a high chance of local retention and rapid re-recruitment (Strathmann et al. 2002), but risks overcrowding, limits the effective range of larvae dispersal due to limited energy reserves and is much more reliant on adult rafting for delivering larvae to new habitats (Highsmith 1985, Cragg et al. 2009). Short-term brooding, however, strikes a balance between lower fecundity and a high rate of fertilization success. This results in developed planktotrophic larvae with a higher chance of being locally retained, but with the ability to survive long dispersal periods in search of new suitable substrata, all characteristics of effective opportunistic species (Grassle \& Grassle 1974). Short-term brooding shipworms, so equipped, outcompete other reproductive modes and are generally the most geographically widespread (Turner 1966). Long-term brooders, limited by short dispersal, are often constrained to rafting or fewer source populations (Cragg et al. 2009), while broadcast-spawning genera, incorporating the more basal members of the family, are more common in brackish or cold water locations (Turner 1966), deeper offshore wood sinks, or large reservoir habitats such as mangrove swamps (Cragg 2007).

This research shows that shipworms are an ideal model group with which to examine metacommunities inhabiting patchy, ephemeral habitats. Shipworms are a fascinating confluence of recruitment/ dispersal tradeoffs, the constraints of a sessile lifestyle, and specialized habitat. For shipworms, the 'middle of the road' strategy of short-term brooding is most effective at balancing reproductive output, local recruitment, and longer range dispersal, and competition between species can be lessened through different peak spawning seasons. With this work focusing on larval supply and recruitment, further research on this group has the potential to examine the ecological paradigms of $\mathrm{r} / \mathrm{K}$ selection between reproductive modes, and the carry-on effects of competition and overcrowding on fitness.
Acknowledgements. We wish to thank Dr. L. Cookson for providing insight and the timber materials for this project, the staff at the Malacology section at the Australian Museum for access to specimens for comparison, and to A. Tyldsley, E. Janson and N. Watts for providing muchneeded assistance in processing and quantifying the large number of specimens retrieved in this research. Three anonymous reviewers provided insightful contributions, improving the final quality of this manuscript. Credit for the map in Fig. 2 goes to T. Simmonds of the Australian Institute of Marine Science. H.M. was supported by JCU Postgraduate Research and Endeavour International Postgraduate Research Scholarships, and a grant from the Linnaean Society of New South Wales.

\section{LITERATURE CITED}

Alix C (2005) Deciphering the impact of change on the driftwood cycle: contribution to the study of human use of wood in the Arctic. Global Planet Change 47:83-98

Blueweiss L, Fox H, Kudzma V, Nakashima D, Peters R, Sams S (1978) Relationships between body size and some life-history parameters. Oecologia 37:257-272

- Burgess SC, Marshall DJ (2011) Are numbers enough? Colonizer phenotype and abundance interact to affect population dynamics. J Anim Ecol 80:681-687

Cadotte MW, Mai DV, Jantz S, Collins MD, Keele M, Drake JA (2006) On testing the competition-colonization tradeoff in a multispecies assemblage. Am Nat 168:704-709

Caley MJ, Carr MH, Hixon MA, Hughes TP, Jones GP, Menge BA (1996) Recruitment and the local dynamics of open marine populations. Annu Rev Ecol Syst 27: 477-500

Calloway CB, Turner RD (1988) Brooding in the Teredinidae (Mollusca: Bivalvia). In: Thompson MF, Sarojini R, Nagabhushanam R (eds) Marine biodeterioration: advanced techniques applicable to the Indian Ocean. Proc Intl Conf Mar Biodet. Oxford \& IBH, New Delhi, p 215-226

Chadwick NE, Morrow KM (2011) Competition among sessile organisms on coral reefs. In: Dubinsky Z, Stambler N (eds) Coral reefs: an ecosystem in transition. Springer, Dordrecht, p 347-371

Clarke KR, Gorely RN (2006) PRIMER v6. PRIMER-E, Plymouth

Cookson LJ (1990) A laboratory bioassay method for testing preservatives against the marine borers Limnoria tripunctata, L. quadripunctata (Crustacea) and Lyrodus pedicellatus (Mollusca). The International Research Group on Wood Preservation IRG/WP/4160, Rotorua

Cookson LJ, Woods TL (1995) Laboratory method used to test the effectiveness of chlorothalonil against marine borers. Wood Protection 3:9-15

Cookson LJ, Scown DK (1999) Recent marine wood preservation research in Australia. In: Lewis JA (ed) 10th Int Congr Mar Corrosion Fouling, University of Melbourne, February 1999. Defence Sci Technol Organ, DSTO-GD0287, Melbourne, p 172-195

Cowen RK, Sponaugle S (2009) Larval dispersal and marine population connectivity. Annu Rev Mar Sci 1:443-466

Cragg SM (2007) Marine wood boring invertebrates of New Guinea and its surrounding waters. In: Beehler B, Marshall A (eds) The ecology of Papua. Periplus, Singapore, p 539-563

> Cragg SM, Jumel MC, Al-Horani FA, Hendy IW (2009) The 
life history characteristics of the wood-boring bivalve Teredo bartschi are suited to the elevated salinity, oligotrophic circulation in the Gulf of Aqaba, Red Sea. J Exp Mar Biol Ecol 375:99-105

Culliney JL (1975) Comparative larval development of the shipworms Bankia gouldi and Teredo navalis. Mar Biol 29:245-251

Giesel JT (1976) Reproductive strategies as adaptations to life in temporally heterogeneous environments. Annu Rev Ecol Syst 7:57-79

Grassle JF, Grassle JP (1974) Opportunistic life histories and genetic systems in marine benthic polychaetes. J Mar Res 32:253-284

Haderlie EC (1983) Long-term natural resistance of some Central American hardwoods to attacks by the shipworm Bankia setacea (Tryon) and the gribble Limnoria quadripunctata Holthius in Monterey Harbor. Veliger 25: 182-186

Haderlie EC, Mellor JC (1973) Settlement growth rates and depth preference of the shipworm Bankia setacea in Monterey Bay. Veliger 15:265-286

Hadfield MG, Strathmann MF (1996) Variability, flexibility and plasticity in life histories of marine invertebrates. Oceanol Acta 19:323-334

Hanski I (1999) Metapopulation ecology. Oxford University Press, New York, NY

> Hanski I (2008) Spatial patterns of coexistence of competing species in patchy habitat. Theor Ecol 1:29-43

Highsmith RC (1985) Floating and algal rafting as potential dispersal mechanisms in brooding invertebrates. Mar Ecol Prog Ser 25:169-179

> Hinojosa IA, Rivadeneira MM, Thiel M (2011) Temporal and spatial distribution of floating objects in coastal waters of central-southern Chile and Patagonian fjords. Cont Shelf Res 31:172-186

Ibrahim JV (1981) Season of settlement of a number of shipworms (Mollusca: Bivalvia) in six Australian harbours. Aust J Mar Freshwater Res 32:591-604

Junqueira AOR, Omena EP, de Silvia SHG (1991) A comparative study on the methods used to evaluate the activity of Teredinidae molluscs. J Exp Mar Biol Ecol 150:107-115

Kawecki TJ, Stearns SC (1993) The evolution of life histories in spatially heterogeneous environments: optimal reaction norms revisited. Evol Ecol 7:155-174

Koehl MAR, Hadfield MG (2010) Hydrodynamics of larval settlement from a larva's point of view. Integr Comp Biol 50:539-551

Krug PJ (2001) Bet-hedging dispersal strategy of a specialist marine herbivore: a settlement dimorphism among sibling larvae of Alderia modesta. Mar Ecol Prog Ser 213: $177-192$

Leibold MA, Holyoak M, Mouquet N, Amarasekare P and others (2004) The metacommunity concept: a framework for multi-scale community ecology. Ecol Lett 7:601-613

- Levin LA (2006) Recent progress in understanding larval dispersal: new directions and digressions. Integr Comp Biol 46:282-297

Levin SA, Whitfield M (1994) Patchiness in marine and terrestrial systems: from individuals to populations [and

Editorial responsibility: Steven Morgan,

Bodega Bay, California, USA discussion]. Philos Trans R Soc Lond B 343:99-103

> Levins R, Culver D (1971) Regional coexistence of species and competition between rare species. Proc Natl Acad Sci USA 68:1246-1248

Levitan D (1995) The ecology of fertilization in free-spawning invertebrates. CRC Press, Boca Raton, FL

> Logue JB, Mouquet N, Peter H, Hillebrand H (2011) Empirical approaches to metacommunities: a review and comparison with theory. Trends Ecol Evol 26:482-491

> Manyak DM (1982) A device for the collection and study of wood-boring molluscs: application to boring rates and boring movements of the shipworm Bankia gouldi. Estuaries 5:224-229

Marshall DJ, Keough MJ (2009) Does interspecific competition affect offspring provisioning? Ecology 90:487-495

McPeek MA, Holt RD (1992) The evolution of dispersal in spatially and temporally varying environments. Am Nat 140:1010-1027

Nair NB, Saraswathy M (1971) The biology of wood-boring Teredinid molluscs. Adv Mar Biol 9:335-509

Pineda J, Reyns N, Starczak V (2009) Complexity and simplification in understanding recruitment in benthic populations. Popul Ecol 51:17-32

Scheltema RS (1971) Dispersal of phytoplanktotrophic shipworm larvae (Bivalvia: Teredinidae) over long distances by ocean currents. Mar Biol 11:5-11

Scheltema RS (1988) Initial evidence for the transport of teleplanic larvae of benthic invertebrates across the East Pacific Barrier. Biol Bull 174:145-152

Shanks AL (1995) Mechanisms of cross-shelf dispersal of larval invertebrates and fish. In: McEdward I (ed) Ecology of marine invertebrate larvae. CRC Press, Boca Raton, FL, p 323-368

Smith ML (1963) The Teredinidae of the Queensland coast from Cairns to Brisbane. MSc thesis, University of Queensland, Brisbane

Spencer M, Tanner JE (2008) Lotka-Volterra competition models for sessile organisms. Ecology 89:1134-1143

Strathmann RR, Strathmann MF (1982) The relationship between adult size and brooding in marine invertebrates. Am Nat 119:91-101

Strathmann RR, Hughes TR, Kuris AM, Lindeman KC, Morgan SG, Pandolfi JM, Warner RR (2002) Evolution of local recruitment and its consequences for marine populations. Bull Mar Sci 70:377-396

> Swearer SE, Caselle JE, Lea DW, Warner RR (1999) Larval retention and recruitment in an island population of a coral-reef fish. Nature 402:799-802

Travis JMJ, Dytham C (1999) Habitat persistence, habitat availability and the evolution of dispersal. Proc R Soc Lond B 266:723-728

Turner RD (1966) A survey and illustrated catalogue of the Teredinidae. Museum of Comparative Zoology, Harvard University, Cambridge, MA

- Vaughn D, Allen JD (2010) The peril of the plankton. Integr Comp Biol 50:552-570

> Yund PO (2000) How severe is sperm limitation in natural populations of marine free-spawners? Trends Ecol Evol 15:10-13

Submitted: January 27, 2012; Accepted: May 14, 2012

Proofs received from author(s): July 31, 2012 